\title{
COVID-19 Hastalarında Yoğun Bakım Yaklaşımı
}

\author{
Hilal AYOĞLU ๑ه \\ Zonguldak Bülent Ecevit Üniversitesi, Tıp Fakültesi, Anesteziyoloji ve Reanimasyon Anabilim Dalı, Zonguldak, Türkiye \\ Bu makaleye yapılacak atıf: Ayoğlu H. COVID-19 Hastalarında Yoğun Bakım Yaklaşımı. Türk Diyab Obez 2020;2: 183-193.
}

\begin{abstract}
ÖZ
COVID-19 pandemisi sürecinde ağır hemodinamik bozukluklar, ağır pnömoni, solunum yetmezliği, akut solunum sıkıntısı sendromu (ARDS), organ hasarı, sepsis, septik şok gibi sorunları olan kritik hastaların yoğun bakım yönetiminde; yoğun bakıma ihtiyacı olan hastaların belirlenmesi, tedavisi, bu süreçte yoğun bakımların dizaynı gibi pek çok farklı konuyu içeren klinik araştırmalar, derlemeler, kılavuzlar yayınlanmıştır. Pandemi sürecinde yoğun bakım görevlilerinin bilgi ve tecrübeleri her geçen gün giderek artmaktadır. Bu makale Mart-Haziran 2020 ayları arasında gerek ülkemiz gerekse de yurt dışı uygulamalarda erişkin COVID-19 hastalarının yoğun bakım yönetimi hakkında önerilen bilgiler ışı̆̆ında derlenmiştir.
\end{abstract}

Anahtar Sözcükler: COVID-19, Yoğun bakım yaklaşımı

\section{Intensive Care Approach in COVID-19 Patients}

\begin{abstract}
In the intensive care management of critical patients with severe hemodynamic disorders, severe pneumonia, respiratory failure, acute respiratory distress syndrome (ARDS), organ damage, sepsis and septic shock during the COVID-19 pandemic process; clinical researches, reviews, guides have been published which include many different topics such as the identification, treatment of patients who need intensive care and the design of intensive care in this process. The knowledge and experience of intensive care staff are increasing day by day in the pandemic process. This article was compiled in the light of the recommended information about intensive care management of adult COVID-19 patients from March to June 2020 both in our country and abroad.
\end{abstract}

Key Words: COVID-19, Intensive care management

\section{GíRİş}

Aralık 2019'da bir halk sağlığı tehdidi olarak ortaya çıkan ve Şiddetli Akut Solunum Sendromu'na (SARS-CoV-2) neden olan yeni tip koronavirüs (nCOVID-19) Mart 2020'de Dünya Sağlık Örgütü tarafindan pandemi etmeni olarak ilan edilmiştir (1). COVID-19 ile enfekte kişilerde klinik \%81 oranında hafif seyir göstermekle beraber, \%14'ü ağır seyretmekte, hastaların \%5'i yoğun bakım ihtiyacı duymaktadır (2). Yoğun bakımda yatan COVID-19 hastalarına ait farklı mortalite oranları $(\% 30,9-67)$ belirtilmekle birlikte morbiditeler ile ilgili veriler henüz mevcut değildir $(3,4)$.

\section{COVID-19 Evreleri ve Hastalığın Şiddeti}

COVID-19 enfeksiyon bulguları konağın immün yanıtına, komorbid hastalıklarına göre asemptomatik olabildiği gibi hafif, orta, ağır ya da kritik şekilde seyredebilmektedir. Hafif seyreden hastalarda, görüntülemede pnömoni belirtisi yoktur, orta şiddette seyreden olgularda pnömoninin radyolojik bulguları ile ateş ve solunum yolu semptomları gözlenirken şiddetli seyreden olgularda dispne, solunum frekans1 $\geq 30 / \mathrm{dk}$, kan oksijen satürasyonu $\leq \% 93, \mathrm{PaO}_{2} / \mathrm{FiO}_{2}$ oran $1<300$ ve/veya $24-48$ saat içinde $>\% 50$ akciğer infiltrasyonları mevcuttur (5). 
Kritik seyirli olgularda solunum yetmezliği [ağır solunum yolu enfeksiyonu (ağır pnömoni), ARDS], septik şok ve/veya çoklu organ fonksiyon bozukluğu/yetmezliği [miyokardit, aritmiler, kardiyojenik şok, metabolik asidoz, koagülasyon sorunları, endokrinopatiler, akut böbrek hasarı, hepatik disfonksiyon, nörolojik ve nöropsikiatrik komplikasyonlar vb.] görülebilir $(5,6)$.

Erişkin yoğun bakımlarda semptom başlangıcından itibaren hastalık sürecinin tüm hastalarda nasıl seyredeceğinin tahmini hâlen zor olmakla birlikte genel seyirde hastalık üç evre ile karşımıza çıkmaktadır. Enfeksiyonun erken evresinde (viral yanıt fazı); hafif semptomlar, kuru öksürük, ishal, baş ağrısı vb. şikayetleri ile karşılaşılabilir. Bu dönemde lenfopeni, artmıs protrombin zamanı, D-Dimer ve Laktat Dehidrojenaz (LDH)'da yükselme mevcuttur. İkinci evrede (pulmoner faz) nefes darlığ $\mathrm{FiO}_{2} \leq 300 \mathrm{mmHg}$, akciğer görüntülemelerinde anormallikler, transaminazlarda yükselme, düşük/normal prokalsitonin seviyeleri görülür. Üçüncü evrede (hiperinflamasyon fazı); konakçının inflamatuar yanıtı giderek artar. ARDS, Sistemik İnflamatuar Yanıt Sendromu (SIRS), şok, kalp yetmezliği, multi organ disfonksiyon tabloları ile karşılaşılabilir. Bu dönemde inflamatuar belirteçler (CRP, LDH, IL-6, D-Dimer, ferritin) artmıştır. Troponin ve pro-BNP yükseklikleri görülebilir (7).

COVID-19' da ağır hastalık tablosunda görülen solunum yetmezliği sıklıkla hipoksemik solunum yetmezliği şeklindedir. İleri yaş, komorbid hastalık varlığı (kardiyovasküler hastalık, diyabet, kronik respiratuar hastalık, hipertansiyon, kanser), erkek cinsiyet ağır hastalık gelişimi için risk faktörleridir (8).

COVID-19 pnömonisinde radyolojik incelemelerde bilgisayarlı toraks tomografilerinde (BT) karakteristik olarak bilateral lobüler tarzda, periferik ve bazal yerleşimli, yaygın yamalı multifokal buzlu cam opasiteleri göze çarpar. COVID-19 pnömonisi BT bulguları radyolojik seyrine göre dört evrede sinıflandırılmıştır:

1. Erken dönem (0-4 gün): Buzlu cam opasiteleri, alt loblarda sıklıkla bilateral tutulum

2. Progresyon dönemi (5-8 gün): Hızlı progresyon, bilateral multilober buzlu cam opasiteleri

3. Pik evre (9-13 gün): Tutulum gösteren alanlarda yavaş progresyonla yoğun konsolidasyonlar

4. Rezolüsyon evresi (14. günden sonrası): Enfeksiyonun kontrol altına alınmasıyla 26. güne kadar uzayabilen radyolojik dansitelerin gerilemesi (9).

\section{COVID-19 Șüphesi/Tanısı Olan Hastalarda Yoğun}

\section{Bakıma Kabul}

COVID-19 hastalarında; ciddi akut solunumsal enfeksiyon (SARI), ağır pnömoni ARDS ve sepsis meydana geldiğinde hastaların yoğun bakımlarda izlenmesi ve tedavisi gerekmektedir. Yoğun bakıma (YB) kabuller hastalığın şiddetine ve sağlık bakım sisteminin YB kapasitesine bağlıdır (10). YB ihtiyaçlarının azaltılması için ön tedavilerin uygun şekilde düzenlenmesi gereklidir.

Kritik durumdaki hastaların tanınması ve etkin tedavisi bazı kardiyak arrestleri, ölümleri ve yoğun bakım ünitesine beklenmeyen yatışları önlemede son derece önem taşır. Erken uyarı skorlama sistemlerine göre solunum sayısı, oda havasındaki oksijen saturasyonu, oksijen destek ihtiyacı varlığı, sistolik kan basıncı, nabız hızı, bilinç düzeyi, vücut 1sısı değişiklikleri vb. fizyolojik parametrelerde normalden sapmalara göre alınan puanlar ile hastaların durumları daha kötüye gitmeden ileri düzeyde bakım koşullarının sağlanması ve yoğun bakıma yatış kararları verilebilir. COVID-19 hastasının erken uyarıları dikkate alınarak yoğun bakıma yatışına karar verilmesi, gecikmelere bağlı oluşabilecek sorunları (ilerleyici solunum yetmezliği, sepsis vb.) önleyeceği gibi alınan önlemler ile invaziv mekanik ventilasyon ihtiyacının azaltılması da tedavi sürecini olumlu yönde etkileyecektir. COVID-19'da hızlı klinik kötüleşme ile sıklıkla karşılaşılmaktadır. Pandemi sürecinde COVID-19 şüpheli hastalarda YB yatış endikasyonu verilmişse öncelikle hastanın COVID triaj yoğun bakımına alınması, sonrasında tanısal test sonuçlarına göre COVID pozitif ise COVID-19 kohort yoğun bakımına alınması önerilmektedir $(11,12)$.

\section{Yoğun Bakım Tedavisi Gereken Hastalar}

Akciğer grafisi veya toraks tomografisinde bilateral infiltrasyonlar veya multi-lober tutulum varlığı, dispne ve solunum güçlügü, takipne (solunum sayısının $>30 / \mathrm{dk}$.), izlemde $\mathrm{O}_{2}$ ihtiyacı artı̧̧ı, $>5 \mathrm{~L} / \mathrm{dk}$. oksijen desteğine rağmen $\mathrm{SpO}_{2}<\% 90$ ve $\mathrm{PaO}_{2}<70 \mathrm{mmHg}, \mathrm{PaO}_{2} / \mathrm{FiO}_{2}:<300$ olmas1, hipotansiyon: sistolik kan basıncı (SKB) $<90 \mathrm{mmHg}$ ve olağan SKB'dan 40 mmHg'dan fazla düşüş ve Ortalama Arter Basıncı $(O A B)<65$ mmHg olması, taşikardi:>100/dk., akut böbrek hasarı, karaciğer fonksiyon testlerinde bozukluk, miyokardit, aritmi, kardiyojenik şok, konfüzyon, akut kanama diyatezi gibi akut organ disfonksiyonu gelişimi, immunsüpresyon gelişmesi, troponin yüksekliği, laktat $>2 \mathrm{mmol}$, uzamış kapiller geri dolum ve cilt perfüzyon bozukluğu varlığında YB yatışı gerekir (11-13).

\section{COVID-19 Hastalarında Yoğun Bakım Takibi}

Yoğun bakıma yatış endikasyonu olan hastalar hızla klinik kötüleşme gösterebileceğinden vital bulguları (kalp hızı, 
ritmi, solunum sayıs1, kan basıncı, vücut 1sısı, oksijen satürasyonu) düzenli olarak takip edilir. İlerleyici solunum yetmezliği ve sepsis açısından dikkatli olunmalıdır. Hastaların tam kan sayımı (özellikle lenfosit sayısı), rutin biyokimyasal parametrelere ilave C-reaktif protein, troponin, D-dimer, ferritin, prokalsitonin seviyeleri, böbrek ve karaciğer fonksiyonları, kardiyak enzimleri, koagülasyon parametreleri (fibrinojen, PT/aPTT), arter veya venöz kan gazı, laktat, elektrolit değerleri, akciğer grafisi yatı̧ sırasında istenir ve düzenli aralıklarla takip edilir. Antibiyotik tedavisi öncesinde kültürleri alınır. Hastalar YB yatışı sırasında komorbid hastalıkları açısından da değerlendirilmeli ve öncesinde kullanılan tedavi rejimleri de düzenlenmelidir. COVID19 'da hipertansiyon ve diyabet en sık görülen komorbid hastalıklardır (13-14).

Ayrıca hastaların sitokin paneli ve anjiotensin II seviyesi değerlendirilmeli, günlük EKG çekimleri yapılmalı, QTc uzamasına neden olabilecek ilaç etkileşimlerinden kaçınılmalı, klinik kötüleşmede akciğer X-ray, USG takipleri yapılmalıdır. Troponin seviyesi yükselecek olursa sol ventrikül fonksiyonları değerlendirilmelidir.

\section{COVID-19 Hastalarında Yoğun Bakım Tedavileri}

\section{Yoğun Bakım Sıvı Tedavisi}

Yoğun bakıma yatırılan şok tablosu olmayan hastalarda konservatif sıvı tedavisi başlanır. Kontrolsüz uygulanan sıvı tedavisinin oksijenizasyonu kötüleştirebileceği unutulmamalıdır. COVID-19 ve ARDS olan mekanik ventile edilen hastalarda da liberal yerine konservatif sıvı stratejisi önerilmektedir.

COVID-19 ve şok tablosunda, sıvı yanıtını değerlendirmek için statik parametreler yerine cilt sıcaklı̆̆g, kapiller geri dolum zamanı ve/veya serum laktat ölçümü gibi dinamik parametrelerin kullanılması önerilmektedir. COVID-19 ilişkili septik şok hastalarında akut sıvı resusitasyonunda vazopressör tedavisi de erken dönemde düşünülmelidir. Siv1 resusitasyonunda da kolloidler yerine kristalloidlerin kullanılması önerilmektedir. Dengeli olmayan kristalloidler yerine tamponlu/dengeli kristalloidlerin kullanılması öneriler arasında yer almaktadır (15).

\section{Vazoaktif Ajanlar}

COVID-19 ve şok durumunda norepinefrinin ilk seçenek olarak kullanılması önerilmektedir. Norepinefrin mevcut değilse vazopressin veya epinefrin kullanılabilir. Norepinefrin mevcutsa dopamin kullanılmaması gereklidir. Ancak hedef OAB'a tek başına norepinefrin ile ulaşılamıyorsa, norepinefrin dozunu titre etmek yerine ikinci basamak ajan olarak vazopressin eklenebilir. Hedef OAB 60-65 mmHg olacak şekilde vazoaktif ajanlar titre edilmelidir. Sıvı resüsi- tasyonu ve norepinefrine rağmen kardiyak disfonksiyon ve inatçı hipoperfüzyon mevcutsa norepinefrin dozunu artırmak yerine dobutamin eklenmesi önerilmektedir. COVID19 ve refrakter şoku olanlarda ise düşük doz kortikosteroid tedavisi uygulanabilir (15). Kortikosteroid kullanımında hiperglisemi, hipernatremi, hipokalemi açısından dikkatli olunmalidir (16).

\section{Hava Yolu Açıklığının Sağlanması-Solunumun Desteklenmesi}

\section{Pandemide aciliyet yoktur!}

COVID-19 pandemisi sürecinde YB ihtiyacı olan hastalara uygulanacak ișlemler beraberinde sağlık çalıșanlarına bulaş riski taşımaktadır. Yoğun bakımlarda özellikle hava yolu açıklığının sağlanması ve idamesi sırasında entübasyon, ekstübasyon işlemleri, trakeostomi, non invaziv mekanik ventilasyon (BIPAP maske uygulaması), yüksek akımlı nazal oksijen uygulaması (HFNO), bronkoskopi, balon-valfmaske uygulamaları, kardiyopulmoner resusitasyon (KPR) vb. işlemlerinin aerosol oluşturma riskleri mevcuttur (17).

$\mathrm{Bu}$ işlemler öncesinde klinik karar verme son derece önem taşır. Her aerosol oluşturan işlem öncesinde sağlık çalışanları kişisel koruyucu ekipmanı (KKE) [su geçirmez önlük, maske (N95/FFP2/ Motorlu hava temizleme respiratörleri-PAPR), gözlük/yüz koruyucu siperlik ve eldiven] tam olarak uygulamalıdır. KKE'lar giyilirken ve çıkartılırken kurallara uyulmalıdır. Özellikle maskenin odadan çıkınca, en son çıkartılması ve sonrasında el hijyeni uygulanması ihmal edilmemelidir (15). KKE kullanımında çalışanlar birbirini kontrol etmeli ve ekip üyelerinin tam olarak korunup korunmadığından emin olmalıdır. Çalışan ve hasta güvenliğini sağlamak için kontrol listelerinden yararlanılmalıdir.

Periferik oksijen satürasyonu $\left(\mathrm{SpO}_{2}\right)<\% 92$ ise oksijen desteğine başlanmalıdır (15-18).

Oksijen tedavisi konvansiyonel düşük akım (<15L/dk.) veya yüksek akım yöntemleri ile uygulanabilir. Nazal kanül ile en fazla $6 \mathrm{~L} / \mathrm{dk}$. oksijen verilebilir, bu yöntemde ulaşılan $\mathrm{FiO}_{2} \% 45$ civarındadır. $6 \mathrm{~L} / \mathrm{dk}$. üzeri oksijen ihtiyacı olan hastalarda basit yüz maskesi ile 5-8 L/dk. oksijen verilirken ulaşılan $\mathrm{FiO}_{2} \% 60$, rezervuarlı (geri solumasız) maske ile 10-15 L/dk. oksijen akım hızı ile ulaşılan $\mathrm{FiO}_{2} \% 85$ 'tir. Altı saatten fazla süre ile $\mathrm{FiO}_{2}$ 'nin \%60' in üzerinde uygulanmasının oksijen toksisitesine yol açabileceği tedaviler sırasında unutulmamalıdir.

Akut hipoksemik solunum yetmezlikli erişkinlerde tedavide, $\mathrm{SpO}_{2} \%$ 92-96 olacak şekilde uygun ara yüz (nazal kanül, oksijen maskesi) ile oksijen desteği sağlanması önerilir. COVID-19'da hipoksemik hastalarda damlacak yolu ile 
enfeksiyon bulaşma riskinin azaltılması adına nazal oksijen kanülü üzerine cerrahi maske uygulanabilir. Eğer $5 \mathrm{~L} /$ $\mathrm{dk}$. üzerinde akım ihtiyacı varsa yeniden solumaya izin vermeyen rezervuarlı oksijen maskelerinin kullanılması düşünülmelidir. COVID-19 ve konvansiyonel oksijen tedavisine rağmen akut hipoksemik solunum yetmezliği olan yetişkinlerde konvansiyonel oksijen tedavisi yerine yüksek akımlı nazal oksijen (HFNO) tedavisi kullanılması önerilmektedir (16). Yüksek akımlı nazal oksijen tedavisi bir nazal kanül aracılığıyla 60L/dk.'ya kadar çıkan akımla \%100'e varan konsantrasyonda nemlendirilmiş oksijen tedavisinin hastalara uygulandığ havanın ısıtılması ve nemlendirilmesi sağlandığı için nazal kurumaya yol açmaz. HFNO uygulaması sırasında buruna tam oturan bir ara yüz ve düşük akım uygulanması ile virüs saçılımında diğer oksijen desteği uygulamalarına göre artış olmayacağı ya da çok az olacağı düşünülmektedir. Ancak akım hızı arttıkça virüs saçılmasının arttığını gösteren çalışmalar da vardır (19). Non invaziv yöntemler ile oksijen tedavisi uygulanması sırasında yakın monitörizasyon ile hastaların izlenmesi son derece önem taşır. Bu hastaların kliniği hızla bozulabilir ve acil entübasyon ihtiyacı olabilir. HFNO mevcut değilse ve endotrakeal entübasyon için acil bir endikasyon yok ise, non invaziv pozitif basınçlı ventilasyon (NIPPV) yakın izlem ve kısa aralıklarla klinik değerlendirme ile denenebilir (15). Maske NIPPV ve Helmet NIPPV kullanımı ile ilgili olarak çalışan güvenliğinin sağlanması amacı ile çeşitli teknikler kullanılabilir; maskenin üstüne bir naylon şeffaf kap örtülmesi veya bir şeffaf kutu içine hastanın alınması gibi. Helmet maskede inspirasyon ve ekspirasyon kolu olan solunum devrelerinin kullanılması, virüs engelleyici özelliği olan filtrelerin uygulanması önerilebilir. Yoğun sekresyonu olan, hava yolu açılığını koruyamayan, hemodinamik açıdan stabil olmayan veya bilinç bulanıklığı olan hastalarda Helmet maskesi uygulanmamalıdır. NIPPV veya HFNO alan erişkinlerde, solunum yakından izlenmelidir, kötüleşme meydana geldiğinde elektif şartlarda erken entübasyon önerilmektedir. COVID-19 şiddetli hipoksemik solunum yetmezliği olan uyanık, spontan solunum yapan hastalar için pron pozisyonun kullanımının oksijenizasyonu iyileştirebileceği, NIMV sırasında dahi kullanılabileceği de belirtilmiştir (19).

Oksijen tedavisine rağmen hipoksemi, dispne-takipne $>30$ soluk/dk. devam ediyorsa, yardımcı solunum kasları kullaniliyorsa (özellikle sternokloidomastoid), solunumsal alkaloz $\left(\mathrm{PaCO}_{2}<35 \mathrm{mmHg}, \mathrm{pH}>7.45\right)$ mevcut ise entübasyon, konusunda en deneyimli ekiplerce elektif şartlarda gerçekleştirilmelidir $(15,20)$.

Yüksek aerosol riskine karşı işlem sırasında KKE giymiş, en az sayıda kişiyle, entübasyon malzemelerinin önceden hazır olduğu ve entübasyon sırasında maksimum güvenliğin sağlandığı koşullarda, mümkünse negatif basınçlı izole odalarda değilse hepa filtreli ya da cam açılabilir odalarda işlem gerçekleştirilmelidir (21).

Entübasyon sırasında preoksijenizasyon rezervuarlı maske ile yapılmalı, mümkün olduğunca balon-valf maske uygulanmadan işlem gerçekleştirilmelidir. Balon-valf-maske kullanılması gerekiyorsa, maske ile balon arasına virüs filtresi yerleştirilmelidir ve maskenin yüze tam oturduğundan emin olunmalıdır. Düşük tidal volümler ile hasta havalandırılmalıdır. Apneik oksijenasyon düşünülüyorsa 15L/dk. nazal oksijenasyon düşünülmelidir. Hızlı ardışık entübasyon uygulanmalı, öksürüğ̈̈ önlemek için nöromusküler blokaj ile tam kas gevşemesi sağlanmalıdır. Videolaringoskop ve/veya entübasyon kabini ile işlem gerçekleştirilmelidir $(11,15)$. Endotrakeal tüpün kafı şişirilmeden hasta mekanik ventilatöre bağlanmamalı ve havalandırılmamalıdır. Trakeal tüpün yeri kapnografi ile doğrulanmalıdır. Solunum devresi ile endotrakeal tüp arasına filtre yerleştirilmelidir. Mekanik ventilatörlerde çift hatlı devrelerin kullanıldığı cihazlar tercih edilmeli, ekshalasyon hatlarına virüs tutucu filtreler yerleştirilmelidir. Kapalı devre aspirasyon sistemi, hasta ventilatöre bağlanmadan solunum devresine bağlanmalı ve mecbur kalınmadıkça devre bütünlüğü bozulmamalıdır (20). Endotrakeal entübasyon işlemleri için kontrol listelerinin kullanılması hasta sonuçlarını daha olumlu etkileyecektir (22). Hastaların transfer için bir başka ventilatöre aktarılması gibi işlemler sırasında önce ventilatör kapatılmalı ardından entübasyon tüpü klemplenerek hasta ayrilmalıdır. Transfer sirasinda sedasyon ve paralizi, öksürügü ve kişinin kendini ekstübe etmesini önleyebilecektir $(11,23)$.

\section{COVID-19 Akut Solunum Sıkıntısı Sendromu'nda Mekanik Ventilasyon}

Akut Solunum Sikıntısı Sendromu; son bir haftada ortaya çıkan veya kötüleşen solunum sıkıntısı, radyolojik olarak plevral efüzyon, kollaps ile açlklanamayan bilateral opasiteleri, kalp yetmezliği veya volüm fazlalığ ile açılanamayan solunum yetmezliği (transtorasik ekokardiyografi ile sol ventrikül disfonksiyonunun olmadığının gösterilmesi) olarak tanımlanmıştır. ARDS Berlin Kriterlerine göre hafif, orta ve ağır olarak üç farklı klinikle karşımıza çıkabilir (24) (Tablo I).

COVID-19'da ARDS geliştiğinde düşük soluk hacmi (Vt 4-8 mL / kg-tahmini vücut ağırlığı) kullanılması önerilmektedir. Mekanik ventilasyon için $<30 \mathrm{cmH}_{2} \mathrm{O}$ 'luk plato basınçları (Pplat) hedeflenmelidir (15). Orta ve ağır ARDS vakaları için düşük PEEP stratejisi yerine daha yüksek PEEP stratejisi kullanılması önerilir. Yüksek PEEP strate- 
Tablo 1: Berlin Tanı Kriterlerinde Oksijenizasyona göre ARDS Sinıflaması

\begin{tabular}{lcc}
\hline & $\mathrm{PaO}_{2} / \mathrm{FiO}_{2}$ & PEEP \\
\hline Hafif ARDS & $201-300$ & $\geq 5 \mathrm{cmH}_{2} 0$ \\
\hline Orta ARDS & $101-200$ & $\geq 5 \mathrm{cmH}_{2} 0$ \\
\hline Ă̆ır ARDS & $\leq 100$ & $\geq 5 \mathrm{cmH}_{2} 0$ \\
\hline
\end{tabular}

jisi ( $\mathrm{PEEP}>10 \mathrm{cmH}_{2} \mathrm{O}$ ) kullanıliyorsa, hastalar barotravma açısından izlenmelidir. $\mathrm{FiO}_{2}$ mümkün olan en kısa sürede en düşük alt sınıra çekilmelidir. Mekanik ventilasyon (MV) sırasında pnömotoraks, pnömomediastenium, pnömoperikardium, cilt altı amfizemi-hava kaçakları olabileceği göz önünde bulundurulmalıdır $(11,15)$.

Gattinoni ve ark. COVID-19'da hasta akciğerlerinin iki farklı formda olduğunu (L-Tip I ve H-Tip II) ve farklı fenotipik özellikteki hastalara farklı solunum tedavi modaliteleri uygulanması gerektiğini belirtmiştir (25). L tipinde (sessiz hipoksemi); akciğer elastansı düşük, komplians normal ya da yüksek, ventilasyon/perfüzyon oranı bozulmuş, akciğer gaz volümü azalmamış olup, akciğerler daha hafiftir ve daha az rekruite edilir. L tipinde yüksek akım, CPAP, NIMV uygulamaları düşünülmelidir, PEEP düşük, soluk hacmi daha yüksek tutulabilir $(>6 \mathrm{~mL} / \mathrm{kg}$ ), soluk sayısı $20 / \mathrm{dk}$. geçmeyecek şekilde MV ayarlanmalıdır. H tipinde akciğerlerde yüksek elastans-düşük komplians, ağır ARDS mevcuttur. Rölatif yüksek PEEP, düşük tidal volümlü MV tedavisi düşünülmeli, akciğer koruyucu ventilasyon stratejisi uygulanmalıdır. H tipinde sağdan sola şant oranı yüksek, akciğer ağır, gaz volümü azalmış olup rekruitmente iyi cevap verir. Pron pozisyonu özellikle önerilir. MV ayarlarının hastaya özgü olarak düzenlenmesi gereklidir. SpO2>\%90 sağlanacak şekilde en düşük PEEP, en düşük $\mathrm{FiO}_{2}$ en düşük Paw hedeflenmelidir $(25,26)$.

COVID-19'da orta ile şiddetli ARDS olan mekanik olarak ventile edilen yetişkinler için, 12 -16 saat boyunca pron ventilasyon öneriler arasında yer almakla birlikte daha uzun süreli pron pozisyon uygulamaları da gerekebilir (15). Koruyucu akciğer ventilasyonunu kolaylaştırmak için gerektiğinde nöromüsküler bloke edici ajanların (NMBA) aralıklı boluslar halinde kullanılması önerilmektedir. Ventilatöre uyumsuzluk, derin sedasyon gereksiniminin devam etmesi, pron ventilasyon veya inatçı yüksek plato basınçları olması durumunda, 48 saate kadar sürekli NMBA infüzyonu kullanılabilir. Ciddi ARDS'de optimal ventilasyon ve diğer kurtarma stratejilerine rağmen hipoksemi devam ediyorsa kurtarma tedavisi olarak inhale pulmoner vazodilatör denenebilir. Optimal ventilasyona rağmen COVID-19 ve hipoksemisi olan yetişkinler için recruitment manevra- ları kullanılabilir. COVID-19 ve mekanik ventilasyon uygulanan erişkinlerde optimal ventilasyon, kurtarma tedavileri ve pron pozisyona rağmen refrakter hipoksemi devam ediyorsa venö-venöz (VV) ekstra korporeal membran oksijenizasyonu (ECMO) kullanılması veya hastanın bir ECMO merkezine yönlendirilmesi önerilmektedir (15).

\section{COVID-19'da Antibiyotik-Antiviral Ajan Uygulamaları}

COVID-19 hastaları bakteriyel enfeksiyon açısından da değerlendirilmelidir. COVID-19 ve solunum yetmezliği olan mekanik olarak ventile edilen hastalarda, ampirik antimikrobiyal/antibakteriyel ajan kullanılması önerilir (27). Mikrobiyoloji sonuçlarına ve hastanın klinik durumuna göre tedavi ve kapsam spektrumu gözden geçirilmelidir. COVID-19 pandemi sürecinde sepsis tablosu ile gelen hastalara ilk bir saat içinde uygun ampirik antimikrobiyal tedavi başlanmalıdır. Antibiyotik tedavisinin seçimi hastanın kliniği, öyküsü, lokal epidemiyolojik veriler ve enfeksiyon kontrol komitelerince önerilen tedavi rehberlerine göre yapılır. Ağır pnömonide atipik pnömoniyi içeren antibiyotik tedavisi planlanırken influenza veya diğer Respiratuar Sinsisyal Virüs (RSV), Rhino virüs vb. için risk faktörleri var ise diğer antiviraller (oseltamivir, nöraminidaz inhibitörleri vb.) tedaviye eklenebilir (16). Ancak COVID-19'un önlenmesinde veya tedavisinde oseltamivirin etkinliği hakkında herhangi bir sağlam veri yoktur (28).

Pandemi sürecinde COVID-19 tanısı ile gelmemiş şüpheli COVID-19 olgularında üst ve alt hava yollarından (nazofarengeal, oro-farengeal, balgam, endotrakeal aspirat, bronkoalveolar lavaj) PCR örnekleri alınmalıdır bakteriyel ve viral paneller çalıştırılmalıdır. COVID-19 şüphesi olan entübe hastalarda tanısal testlerin, üst solunum yolu (nazofaringeal veya orofaringeal) numuneleri yerine alt solunum yolu (endotrakeal aspirat, bronkoalveoler lavaj) örnekleri olarak alınması önerilmektedir. $(8,9,13,28-33)$.

\section{COVID-19 Hastalığının Ağır Seyretmesinde Risk} Faktörleri

COVID-19 Hastalı̆̆ının seyrini etkileyen risk faktörleri; $>50$ yaş, daha önceden pulmoner hastalık varlığı, $\mathrm{HbAlc}>\% 7.6$, kronik böbrek hastalığı, hipertansiyon ve kardiyovasküler hastalık öyküsü, obezite, transplantasyon ya da immunsüpresan kullanım öyküsü, HIV, CD4 hücre sayısının $<200$ ya da bilinememiş olması, solunum sayısının $>24$ soluk/dk., kalp hızının > 125 atım /dk., $\mathrm{PaO}_{2} / \mathrm{FiO}_{2}<300 \mathrm{mmHg}$, D-dimer $>1000 \mathrm{ng} / \mathrm{mL}, \mathrm{CPK}$ normalin iki katı artış, $\mathrm{LDH}>245$ $\mathrm{U} / \mathrm{L}$, yükselmiş troponin seviyesi, lenfosit sayısı $<0.8$, ferritin $>500 \mathrm{ug} / \mathrm{L}$ olmasıdır. $(8,9,13,28-31)$.

COVID-19 Hastalarında SARS-CoV-2'ye Yönelik Tedavi Henüz COVID-19 için güvenilirliği ve etkinliği kanıtlan- 
mış spesifik bir tedavi bulunmamakla birlikte çalışmalar sürmektedir (13). Günümüz pratiğinde uygulamada kullanılan ajanlar aşağıda belirtilmiştir.

Ağır pnömonili olası/kesin COVID-19 olgularında tedavide eldeki verilerde hidroksiklorokin-klorokin (antimalaryal ajan) ve favipravir önerilmektedir. Klorokin QTc uzaması, hipoglisemi, nöropsişik etkiler ve retinopatiye neden olabilmektedir. Tedavide kullanılıyorsa dikkatli olunmalıdır. Favipravir pürin nükleotidi olup, RNA polimeraz inhibisyonu ile viral replikasyonun önlenmesini sağlamaktadır. $\mathrm{Bu}$ nedenle ağır pnömonili olgularda hidroksiklorokine ilave olarak tedaviye eklenerek kullanılmaktadır. COVID-19 olan kritik hastalarda: lopinavir / ritonavirin rutin kullanımı önerilmemekle birlikte gebelerde kullanımı Sağglık Bakanlığ Rehberi'nde yer almaktadır $(13,15)$.

COVID-19'da mekanik olarak ventile edilen erişkinlerde sistemik kortikosteroidlerin rutin kullanımı önerilmez. Ancak ARDS olgularında, astım veya kronik obstrüktif akciğer hastalığ 1 alevlenmesi veya septik şok gibi durumlarda kullanılabilir $(15,34)$.

Makrofaj aktivasyonu sendromu veya edinsel hemofagositik lenfohistiyositozis COVID-19 hastalarının \%10'unda görülmektedir, standart tedaviye rağmen dirençli ateş, CRP, ferritin, D-Dimer yüksekliği, sitopeni (lenfopeni ve trombositopeni), karaciğer fonksiyon testlerinde bozulma, hipofibrinojenemi, trigliserid yüksekliği ile seyreden hastalık tablosunda akut bir alevlenme durumu söz konusu olabilir (sekonder bakteriyel enfeksiyonlar klinik durumu karıştırabileceğinden prokalsitonin seviyeleri takip edilmelidir) (35). COVID-19'da aşırı immün yanıt sitokin firtınasını tetikleyerek birden fazla hedef organa zarar verebilir. IL-6'daki artışın COVID-19'da solunum yetmezliğinin şiddetlenmesi için klinik bir uyarı olabileceği belirtilmiştir. IL-6'nın inhibisyonu, sitokin konsantrasyonlarını ve akut faz reaktan üretimini azaltabilir (36). Bu dönemde IL-6 inhibitörü olan tosilizumab uygulanabilir (35). Tosilizumab sonrası CRP düşer, akut faz yanıtlarının takibi, IL-6 serum amiloid proteini değerlendirilir. Tedavi etkinliğini değerlendirmek için; inflamasyon bulguları (ateş, lökosit, CRP, ferritin vb.), klinik (hipoksi, solunum yetmezliği, şok ve çoklu organ yetmezliği), karaciğer fonksiyonları, trombosit sayısı takipleri de yapilmalıdır.

Makrofaj aktivasyonu sendromu tedavisinde IL-1 antagonisti Anakinra-Kineret (rekombinant IL-1 reseptör antagonisti) de tedavide önerilmektedir. JAK inhibitörleri, kortikosteroidler, sitokin tutucu filtreler, immün plazma, kök hücre tedavileri de uygulamalar arasında yer almaktadır (35).

COVID-19'dan iyileșen hastalardan elde edilen konvelesan plazmanın SARS-CoV2'ye spesifik antikorlar ile pasif bağışıklık sağlayabilecek potansiyel bir tedavi olabileceği belirtilmiştir (37). Konvelesan plazma kullanımı için tomografi bulgularının COVID-19 ile uyumlu olması ve 24-48 saat içinde akciğer infiltrasyonunda \%50'den fazla artış, 7 gündür düşmeyen ateş, solunum sayısı $>30 / \mathrm{dk}$., $\mathrm{PaO}_{2} / \mathrm{FiO}_{2}<300 \mathrm{mmHg}, 5 \mathrm{~L} / \mathrm{dk}$. ve üstünde nazal oksijen desteğine rağmen $\mathrm{SpO}_{2}<\% 90$ ve $\mathrm{PaO}_{2}<70 \mathrm{mmHg}$, mekanik ventilasyon ihtiyac1, SOFA skorunda en az 2 puanlık artıș, vazopressör ihtiyacı, hızlı klinik kötüleșme (lenfopeni, CRP, sedimentasyon hızı, ferritin, LDH, D-Dimer yüksekliği) olanlarda kullanılması Sağlık Bakanlığı rehberinde yer almaktadır (35). Tedavinin hastalığın alevlenme fazında, ilk 7-14 gün içerisinde kullanımı önerilmektedir. Bu tedavinin planlandığı hastalarda, serum IgA düzeyi bakılarak normal olduğunun kayıt edilmesi gereklidir. IgA eksikliği olan hastalara bu tedavi uygulanamaz (37-39).

COVID-19'lu kritik hastalığı olan yetişkinlerde, standart intravenöz immünoglobulinlerin (IVIG) rutin kullanılması önerilmez (16). COVID-19'lu ateş gelişen kritik hastalarda, asetaminofen / parasetamol kullanılması önerilir (16). Arbidol hidroklorür, virüslerin geniş spektrumlu bir inhibitörüdür COVID-19 tedavisinde kullanımı denenmiştir (40).

C Vitamini: Alveol epitel bariyerini korumakta, protein kanallarını düzenlemekte, alveol sıvısını regüle etmektedir. Plazmadaki hücreden serbest DNA'yı azaltmaktadır. Yüksek doz C Vitamini uygulaması sepsis ve ağır akut solunum yetmezliğinde önerilmekte olup COVID-19 tedavisinde de kullanılmaktadır (41).

D Vitamini: Bağışılklık sisteminde modülatör etkisi mevcuttur. Endotel rejenerasyonu sağlamakta, ARDS'de alveol hasarını iyileştirmekte, koruyucu etkisi nedeni ile önerilmektedir. COVID-19 ağır seyreden olgularda D vitamini düzeylerinin düşük olduğu belirtilmiştir (42).

Beslenme: COVID-19 entübe olmayan hastalarda oral alım yetersiz kaldığında nazogastrik sonda ile enteral nutrisyon sağlanmalıdır. Enteral yol erişimi kısıtlı ise parenteral nutrisyon desteği uygulanabilir. Nazogastrik sonda ile enteral nutrisyonda prokinetik tedaviye rağmen intolerans ya da yüksek aspirasyon riski var ise postpilorik beslenme uygulanabilir. Besin içeriğinde protein 1.3-2g/kg/gün, enerji: 15-20 $\mathrm{kcal} / \mathrm{Kg}$ (aktüel VA)/gün olacak şekilde tercih edilmelidir. Erken fazda standart yüksek protein, polimerik isoosmatik enteral nutrisyon ürünleri tercih edilirken, gastrointestinal sistem disfonksiyonu var ise fiber içeren ürünler eklenmelidir. Mümkünse erken 24-36 saat içerisinde trofik enteral nutrisyon başlanmalıdır. Pron pozisyon uygulanması enteral beslenme için kontrendikasyon oluşturmaz (43).

\section{COVID 19-Akut Böbrek Hasarı}

COVID-19 enfeksiyonu olan hastalarda akut böbrek 
hasarı insidansı yaklaşık \% 3-15 iken yoğun bakım ünitesinde bakım gerektiren ciddi enfeksiyonu olan hastalarda, akut böbrek hasarı oranları \% 15’ten \% 50’ye artmıştır. Akut böbrek hasarı COVID-19 hastalarında mortalite için bağımsız bir risk faktörüdür. COVID-19' da akut böbrek hasarı multifaktöryel etmenlere bağlı ortaya çıabilmektedir. Böbrek dokusuna direkt sitopatik etkileri kan ve idrarda polimeraz zincir reaksiyonu fragmanlarının saptanmasıyla desteklenmiştir. ACE-2 ekspresyonunun böbreklerde fazla oluşu nedeni ile virüsün böbreklere girişinin daha kolay olması, viral antijenlerin immün kompleksi veya virüsün neden olduğu spesifik immünolojik efektör mekanizmaların (spesifik T hücre lenfosit veya antikorunun) birikmesi böbreğe zarar verebilir. Virüsün indüklediği sitokin ya da mediatörlerin böbrekteki direkt etkileri, hipoksi, rabdomiyoliz ve şok gibi etmenlerin hepsi akut böbrek hasarından sorumlu tutulabilir. Yoğun bakım hastalarının renal fonksiyonları yakından izlenmeli, böbrek fonksiyonlarını olumsuz etkileyebilecek ilaç etkileşiminden kaçınılmalıdir. Hastalar sıklıkla renal replasman tedavilerine (RRT) alınmak zorunda kalabilir (44). Şiddetli akut böbrek hasarı olanlarda, RRT’nin başlatılması, üremi, üremik perikardit, hiperkalemi ve metabolik asidoz gibi elektrolit dengesizliği ve hipervolemi gibi durumlarda gerekecektir. ARDS varl1ğında aşırı sıvı yükü zararlı olabilir ve ventilatör desteği yeterli olmayabilir. Bu nedenle, ARDS ve eşlik eden sıvı yüklenmesi durumu olan COVID-19 hastalarında RRT'nin nispeten erken başlaması düşünülebilir (45).

\section{COVID-19 Ekstra Korporeal Membran Oksijenizasyonu} (ECMO)

COVID 19'da oksijenizasyonun düzeltilmesi, karbondioksit atılımının sağlanması ve akciğerlerin dinlenmesi amacı ile konvansiyonel tedavilere dirençli ARDS'lerde VV-ECMO tedavisinin yararlı olabileceği, mortalitede azalma sağladığı belirtilmektedir (46). Optimal ventilasyona rağmen dirençli hipoksemide 6 saatten uzun süredir $\mathrm{PaO}_{2} / \mathrm{FiO}_{2}<80 \mathrm{mmHg}$, 3 saatten uzun süredir $\mathrm{PaO}_{2} / \mathrm{FiO}_{2}<50 \mathrm{mmHg}, 6$ saatten uzun süredir $\mathrm{pH}<7.25, \mathrm{PaCO}_{2} \geq 60 \mathrm{mmHg}$ ise ECMO tedavisi önerilmektedir $(46,47)$. Ancak her merkezde ECMO şansı olamayacağı unutulmamalı, gerekli durumlarda hastalar ECMO uygulanabilecek merkezlere sevk edilmelidir.

\section{COVID-19 Weaning}

Mekanik ventilatörden ayırmak için hastanın ekstübasyona hazır olup olmadığı günlük vizitlerde değerlendirilmelidir. Weaning için hastanın bilincinin açı, kooperasyonun tam olması, hava yolunu koruyabilecek reflekslere, sekresyonunu çıkartabilecek kas gücüne sahip olması ve oksijen ihtiyacının azalmış olması $\left(\mathrm{FiO}_{2}<0.6, \mathrm{PEEP}<7 \mathrm{cmH}_{2} \mathrm{O}, \mathrm{pH}>7.3\right)$ gereklidir. $\mathrm{Bu}$ hastalarda normalde weaning işlemlerinde uygulanan T-tüp denemesi aerosol oluşumunu artırabileceği için önerilmez. Bu hastalar basınç destek moduna alındiktan sonra $\mathrm{PEEP}=5 \mathrm{cmH}_{2} \mathrm{O}$ ve $\mathrm{PSV}=0 \mathrm{cmH}_{2} \mathrm{O}$ ayarlanarak weaning denemesi yapılabilir. CPAP veya PSV modları tercih edilmelidir (21). Ekstübasyonda KKE giyilmeli tüp içi ve ağız içi aspirasyonu takiben ekstübasyon işlemleri başlanmalıdır. Ekstübasyon sırasında önce ventilatör kapatılmalı, kaf indirilerek hasta ekstübe edilmelidir. Ekstübasyon sürecinde hastanın üzeri naylon ile örtülebilir. Ekstübasyon sonrasında nazal oksijen uygularken hastaya cerrahi maske takılmalıdır. MV'den hastayı uygun zamanda ayırdıktan sonra hastalara ihtiyaç durumuna göre NIMV, HFNO, yüz maskesi uygulamaları YB'da yattığı sürece dönüşümlü olarak uygulanabilir.

\section{COVID-19 ve Tromboemboli}

Klinik pratikte, COVID-19 hastalarının yaklaşık \%20'sinde anormal koagülasyon fonksiyonu bulunmakta ve hemen hemen tüm kritik hastalarda koagülasyon bozuklukları ortaya çıkmaktadır (48).

Klok ve ark. çalışmasında COVID-19 enfeksiyonu olan YBÜ hastalarında \%31 oranında trombotik komplikasyon ile karşılaştıklarını belirtmişlerdir (49). Virüs ACE-II reseptörlerine bağlanarak, doğrudan endotel hasarı olușturarak, hareketsizlik ve hastanede yatışla ilişkili staza neden olarak tromoemboliye neden olabilmektedir (35). Vireminin 7. gününde koagülopati belirgin hâle gelmektedir. Hastaların izleminde trombosit sayısı, PT, aPTT, D-Dimer, fibrinojen seviyeleri yakın takip edilmelidir. Hastaların takibinde D-Dimer yüksekliği ve fibrin yıkım ürünleri kötü prognoz göstergesi olarak karşımıza çıabilmektedir. Tüm COVID19 hastalarında aktif kanama veya trombositopeni $(<25-$ $30.000 / \mu l)$ olmadığ 1 sürece tromboz profilaksisi uygulanmalıdır (35). Tromboz profilaksisi kreatin klirensine göre uygulanmalıdır. D dimer $<10 \mathrm{mg} / \mathrm{L}$ ise kontrendikasyon bulunmuyorsa tüm hastalara standart enoksoparin uygulanmalidir. Standart heparin kullanılan hastalarda anti-Xa ile izlem yapılması önerilir. D-Dimer $\geq 10 \mathrm{mg} / \mathrm{dL}$ ise kontrendikasyon olmadıkça kiloya göre enoksoparin proflaksisi uygulanmalıdır (35).

\section{COVID-19'da Kardiyopulmoner Resusitasyon (KPR)}

Durumunda akut kötüleşme veya kalp durması riski altında olan olası COVID-19 hastaları, erken tanınmalıdır. Hastayı değerlendirmek, gögüs kompresyonlarını başlatmak ve kardiyak arrest ritminin tanınması için KKE kullanılmalıdır. KKE kullanma ihtiyac1, COVID-19 olan hastalarda KPR'yi geciktirebilir. Eğitim ve uygulama ile birlikte süreçlerin gözden geçirilmesi, bu gecikmeleri en aza indirecektir. Personel güvenliği her şeyden önce gelmelidir. Hipoksiye sekonder gelişen kardiyak arrestte genellikle oksijen 
ile erken ventilasyon önerilir. Doğru KKE koruması olmadan yapılan herhangi bir hava yolu müdahalesi, kurtarıcıyı ciddi enfeksiyon riskine maruz birakacaktır. Bu nedenlerle COVID-19'da hipoksik arrestlerde bile gögüs kompresyonu ile başlanması önerilmektedir.

COVID-19 pandemisinde yaşam belirtilerinin ve normal solunumun olmadığının görülmesi ile kardiyak arresti doğrulayınız. Eğer eğitiminiz var ise karotis nabzını kontrol ediniz. Kulağınızı ve yanağınızı hastanın ağzına yakın tutarak dinlemeyiniz veya bu şekilde nefes aldığından emin olmaya çalışmayınız. Kardiyak arrest tanısı hakkında herhangi bir şüphe varsa, yapılması gereken yardım gelene kadar göğüs kompresyonlarına başlamaktır.

Yalnızca göğüs kompresyonu ile KPR'yi başlatınız ve hastanın kardiyak arrest ritmini görebilmek için en kısa zamanda monitörize ediniz. Ağızdan ağıza ventilasyondan ve cep maskesi kullanmaktan kaçınınız. Hasta bir yüz maskesi aracılığı ile tamamlayıcı oksijen tedavisi alıyorsa, göğüs kompresyonları sırasında maskenin hastanın yüzünde kalmasını sağlayınız.

Mavi kod ekibinin gelmesinden önce, birimde çalışan personeller (tam KKE giyiyor olacaklar) göğüs kompresyonları devam ederken destek verebilirler. Mavi kod ekibi ve diğer yardımcılar, kardiyak arreste ilk müdahaleyi uygulayan kişiden hastayı devralmadan önce N95/FFP3 maske, önlükler, eldivenler ve göz koruması takmalıdır.

Şok uygulanabilir ritimleri hızla defibrile ediniz - dolaşımın erken restorasyonu, havayolu ve ventilatör desteği ihtiyacını önleyebilir. Ancak COVID-19 hastalarında kardiyak arrest sırasında sıklıkla şoklanamaz ritim ile karşılaşılmaktadır (50).

KPR sırasında odadaki personel sayısı minimumda tutulmalıdır. Kardiyopulmoner resusitasyon sırasinda balon ile hava yolu arasına viral filtre yerleştirilmelidir. Solunum devresinin ayrılmamasına dikkat edilmelidir. Entübe olmayan pron pozisyonundaki hastada kardiyak arrest durumunda, doğru bir şekilde KKE'yi giyerken, göğüs kompresyonlarına başlamadan hemen önce hastanın supin pozisyona dönmesi sağlanmalıdır. Entübe pron pozisyonundaki hastada toraks kompresyonları sırtta her iki skapula arasina basılarak gerçekleştirilebilir. Hasta supin pozisyona çevrilene kadar vital organların perfüzyonu sağlanabilir. Kompresyonlar etkin değilse, havayolunu güvence altına almak gerekiyorsa, dakikalar içinde dolaşım geri dönmediyse hasta supin pozisyona çevrilmelidir (50).

Mekanik ventilatöre bağlı hastaların kompresyon sırasında ventilatörden ayrılmaları önerilmez $\mathrm{FiO}_{2} 1$ olacak şekilde ventilasyon sağlanır. Pron pozisyonda defibrilatör pedleri anterior-posterior ya da biaksiller pozisyonda yerleştiri- lebilir. Ritim ventriküler fibrilasyon/nabızsız ventriküler taşikardi ise tek şok verilmelidir. Hasta şoklanabilir ritimde kalırsa ve KKE kullanılıyorsa, gögüs kompresyonlarına başlanır. KKE yoksa diğer sağlık çalışanları KKE’lerini giyerken endike ise iki ek şok verilebilir (üst üste 3 defa ardışık şok uygulanabilir) (50).

\section{COVID-19 Pandemisinde Yoğun Bakım Yapılanması}

COVID-19 pandemisi sürecinde hastane genelinde fiziksel YB yatak alanlarının kapasitesinin tanımlanması ve artırılması, gereken ekipman, donanım ve işgücü kapasitesinin önceden belirlenerek, gereksinimlerin planlar dahilinde sağlanması gereklidir. Her ne kadar COVID-19 pandemisinde YB'ların negatif basınçlı izole tek kişilik hasta odaları şeklinde olması önerilmekte ise de mevcut şartlarda bu olanakların sağlanması mümkün olamamış, kapısı kapalı penceresi açılabilir tek kişilik odalar da bulunamamışsa, YB kapasitesini artırmak için farklı alanların YB'lara dönüștürülmesi söz konusu olabilir $(51,52)$.

$\mathrm{Bu}$ amaçla perioperatif izleme/derlenme alanları, koroner bakım üniteleri, bazı yerlerde servis yatakları, kullanılmayan YB bölümleri, hizmet dışı bırakılmış kritik bakım alanları gerekli alt yapı sağlanarak (iki oksijen, bir hava, iki aspirasyon çıkışı, 12 hatlı elektrik prizi, monitörizasyon için uygun fiziksel ortam) YB haline dönüştürülebilir (52).

$\mathrm{Bu}$ sürecin yönetiminde mevcut personelin yetersiz kalması nedeni ile YB eğitimi veya deneyimi olan ancak YB'larda çalışmayan hemşireler, çocuk yoğun bakım hemşireleri, hastanenin diğer bölgelerinde kritik hasta deneyimi olan hemşireler (örn: koroner YB bakım hemşireleri), YB ortamına aşina olan klinik aktivitesi azalmış bölümlerdeki hemşireler (örn: anestezi hemşireleri) görev alabilir (52).

Anestezi ekipleri (uzman, asistan, teknisyen, tekniker ve hemşireleri), entübasyon ekipleri oluşturarak, hızlı müdahale ekiplerine liderlik etmek ve yeni kurulan alanlarda çalışan uzmanlara yardımcı olmak için hastane resusitasyon uzmanları olarak görev alabilir.

Daha deneyimli YB personeli, fiziksel olarak YB'dan ayrı olarak yeniden tasarlanmış klinik alanlarda deneyimsiz ekiple birlikte YB hastalarını yönetmek için görevlendirilebilir (52).

Yoğun bakım personeli enfekte olma riski açısından tüm işlemler sürecinde dikkatli olmalıdır. Ekip planlaması olası enfekte personel sayısı da göz önüne alınarak gerçekleştirilmelidir. COVID-19 sürecinde yoğun bakım ziyaretleri kısitlanmalı veya yasaklanmalıdır. Gerekli durumlarda video konferans sistemleri-teletıp hizmetleri kullanılabilir $(10,51)$. 


\section{SONUC}

COVID-19 dünya genelinde pandemi öncesi ve sonrası dönemler olmak üzere tüm hayatı etkilemiş ve etkileyecek gibi görünmektedir. Hastane yöneticileri, hükümetler ve politika yapıcılar; olası ikinci dalga ve diğer pandemiler için YB'larda altyapı, malzeme, personel desteği ile kapasitelerini zorlayabilecek durumlara her zaman hazırlıklı olmalıdır. Hükümetler ve hastane yöneticileri proaktif tutumlar sergileyerek hasta ve çalışan güvenliğini ön plana alarak gerekli düzenlemeler yapmalıdır. Anesteziyoloji ve Reanimasyon Uzmanları eğitimini almıș oldukları konular içerisinde yer alan Yoğun Bakım alanındaki bilgi ve becerileri ile COVID-19 pandemi sürecinin yönetilmesinde liderlik etmiştir. Yoğun bakım çalışanları ileride olası yeni salgınlara hazırlıklı olabilmek için yeni çıkacak yayınlar ile süreci takip etmelidir. COVID-19'a karşı aşı çalışmaları ve tedavi edici ajanların etkisi hâlen netlik kazanmadığı için daha güçlü kanıtlar ile yeni kılavuzlar ve bilgiler ışı̆̆ında tedavi ve korunma sürecine ait bilgiler yenilenmelidir.

\section{Etik Kurul Onayı}

İnsan ve deney ürünü kullanılmadığından etik kurul oluru gerekmemiştir.

\section{Çıkar Çatışması}

$\mathrm{Bu}$ yazı için herhangi bir çıkar çatışması yoktur.

Finansal Destek

Herhangi bir finansal destek alınmamıştır.

Yazarların Makaleye Katkı Beyanı

Yazının tüm sorumluluğu yazara aittir.

\section{Hakem Değerlendirmesi}

Hakemlerin önerileri sonrası yayınlanmaya uygun bulunmuş ve kabul edilmiştir.

\section{KAYNAKLAR}

1. WHO Director-General's opening remarks at the media briefing on COVID-19 - 11 March 2020. (Available: https:// www.who.int/dg/speeches/detail/who-director-generals-opening-remarks-at-the-media-briefing-on-covid19\%2D\%2D-11-march-2020.) [cited 12 Mar 2020].

2. Team NCPERE. Vital surveillances: The epidemiological characteristics of an outbreak of 2019 novel coronavirus diseases (COVID-19) - China. China CDC Weekly. 2020;2(8):113-122.

3. Auld SC, Caridi-Scheible M, Blum JM, Robichaux C et al. ICU and ventilator mortality among critically Ill adults with Coronavirus disease 2019. Crit Care Med. 2020;26:10.1097
4. World Health Organization. Coronavirus disease (COVID-2019) situation reports. 2020. (https://www.who. int/emergencies/diseases/novel-coronavirus-2019/situationreports).

5. Shang Y, Pan C, Yang X, Zhong M, et al. Management of critically ill patients with COVID-19 in ICU: Statement from front-line intensive care experts in Wuhan, China. Ann Intensive Care. 2020;10(1):73.

6. Varatharaj A, Thomas N, Ellul MA, et al. CoroNerve Study Group. Neurological and neuropsychiatric complications of COVID-19 in 153 patients: A UK-wide surveillance study. Lancet Psychiatry. 2020;S2215-0366(20)30287-X. d

7. Siddiqi HK, Mehra MR. COVID-19 Iillness in native and immunosuppressed states: A clinical-therapeutic staging proposal. J Heart Lung Transplant. 2020;39(5):405-407.

8. Wu Z, McGoogan JM. Characteristics of and important lessons from the coronavirus disease 2019 (COVID-19) outbreak in China: Summary of a report of 72314 cases from the Chinese center for disease control and prevention. Jama. 2020 Feb 24. (Online ahead of print).

9. T.C. Sağlık Bakanlığı Halk Sağlığı Genel Müdürlüğü, COVID-19 (SARS-CoV-2 Enfeksiyonu) Ağır Pnömoni, ARDS, Sepsis ve Septik Şok Yönetimi 1 Haziran 2020. (https:// covid19bilgi.saglik.gov.tr).

10. Phua J, Weng L, Ling L, et al. Asian Critical Care Clinical Trials Group Intensive care management of coronavirus disease 2019 (COVID-19): challenges and recommendations. Lancet Respir Med. 2020;8(5):506-517.

11. Karabıyık L. COVID-19 hastaların yoğun bakım süreci. Gazi Medical Journal 2020;31:331-336

12. Centers for Disease Control and Prevention. Interim infection prevention and control recommendations for patients with suspected or confirmed coronavirus disease 2019 (COVID-19) in healthcare settings. (June 19, 2020. https:// www.cdc.gov/coronavirus/2019-ncov/hcp/infection-controlrecommendations.html).

13. T.C. Sağlık Bakanlığı Halk Sağlığı Genel Müdürlüğü, COVID-19 (SARS-CoV-2 Enfeksiyonu) Erişkin Hasta Tedavisi. (19 Haziran 2020. https://covid19bilgi.saglik.gov. tr/depo/rehberler/covid-19-rehberi/COVID-19_REHBERI_ ERISKIN_HASTA_TEDAVISI.pdf).

14. Guan W, Liang W, Zhao Y, et al. China Medical Treatment Expert Group for COVID-19. Comorbidity and its impact on 1590 patients with COVID-19 in China: A nationwide analysis. Eur Respir J. 2020;55(5):2000547.

15. Alhazzani W, Moller MH, Arabi YM, et al. Surviving Sepsis Campaign: Guidelines on the management of critically Ill adults with coronavirus disease 2019 (COVID-19). Intensive Care Med. 2020;46:854-887.

16. Lamontagne F, Rochwerg B, Lytvyn L, Guyatt HG, Moller $\mathrm{MH}$, Annane D. Corticosteroid therapy for sepsis: A clinical practice guideline. BMJ. 2018;362:k3284. 
17. Tran K, Cimon K, Severn M, Pessoa-Silva CL, Conly J. Aerosol-Generating procedures and risk of transmission of acute respiratory infections: A systematic review. PLoS One. 2012;7(4):e35797.

18. Clinical management of COVID-19. Interim guidance 27 May 2010. World Health Organization. WHO72019-nCoV/ clinical/2020.5. (https://apps.who.int/iris/handle/10665/332196).

19. Coppo A, Bellani G, Winterton D, et al. Feasibility and physiological effects of prone positioning in non-intubated patients with acute respiratory failure due to COVID-19 (PRON-COVID): A prospective cohort study. Lancet Respir Med. 2020;8(8):765-774.

20. Agarwal A, Basmaji J, Muttalib F, et al. High-Flow nasal cannula for acute hypoxemic respiratory failure in patientswith COVID-19: Systematic reviews of effectiveness and its risks of aerosolization, dispersion, and infection transmission. Can J Anaesth. 2020;67(9):1217-1248.

21. Talan L, Altıntaș ND. Yoğun Bakımda Hasta Yönetimi/ COVID-19. Ankara Üniversitesi Tip Fakültesi. Ankara Üniversitesi Basımevi 2020. (E-kitap).

22. Turner JS, Bucca AW, Propst SL, Ellender TJ, Sarmiento EJ, Menard LM, Hunter BR. Association of checklist Use in endotracheal intubation with clinically important outcomes a systematic review and meta-analysis. JAMA Netw Open. 2020;3(7):e209278.

23. Goh KJ, Wong J, Tien JC, Ng SY, Duu Wen S, Phua GC, Leong CK. Preparing your intensive care unit for the COVID-19 pandemic: Practical considerations and strategies. Crit Care. 2020;24(1):215.

24. Fan E, Brodie D, Slutsky AS. Acute respiratory distress syndrome: Advances in diagnosis and treatment. JAMA. 2018;319(7):698-710.

25. Gattinoni L, Chiumello D, Rossi S. COVID-19 pneumonia: ARDS or not? Crit Care. 2020;24(1):154.

26. Gattinoni L, Chiumello D, Caironi P, Busana M, Romitti F, Brazzi L, Camporota L. COVID-19 pneumonia: Different respiratory treatments for different phenotypes? Intensive Care Med. 2020;46(6):1099-1102.

27. Tobaiqy M, Qashqary M, Al-Dahery S, Mujallad A, Hershan AA, Kamal MA, Helmi N. Therapeutic management of patients with COVID-19: A systematic review. Infection Prevention in Practice. 2020;2(3):100061.

28. Srinivas P, Sacha G, Koval C. Antivirals for COVID-19. Cleve Clin J Med. 2020 May 14. (Online ahead of print).

29. Yang X, Yu Y, Xu J, et al. Clinical course and outcomes of critically ill patients with SARS-CoV-2 pneumonia in Wuhan, China: A single-centered, retrospective, observational study. Lancet Respir Med; 2020;8(5):475-481.

30. Wang $\mathrm{D}, \mathrm{Hu} \mathrm{B}, \mathrm{Hu} \mathrm{C}$, et al. Clinical Characteristics of 138 Hospitalized Patients with 2019 Novel Coronavirus-Infected Pneumonia in Wuhan, China. JAMA. 2020;323(11):10611069.
31. Ruan Q, Yang K, Wang W, Jiang L, Song J. Clinical predictors of mortality due to COVID-19 based on an analysis of data of 150 patients from Wuhan, China. Intensive Care Med. 2020; 46:846-8.

32. Zitek T. The Appropriate Use of Testing for COVID-19. West J Emerg Med. 2020;21(3):470-472.

33. Zhang L, Wang M, Wang Y, Zhu J, Zhang N. Focus on a 2019-novel coronavirus (SARS-CoV-2). Future Microbiol. 2020;10.2217/fmb-2020-0063.

34. Russell CD, Millar JE, Baillie JK. Clinical evidence does not support corticosteroid treatment for 2019-CoV lung injury. Lancet. 2020;395:473-475.

35. T.C. Sağlık Bakanlığı Halk Sağlığı Genel Müdürlügüu, COVID-19 Rehberi Antisitokin antiinflamatuar tedaviler koagulopati yönetimi. (https://covid19bilgi.saglik.gov.tr/ depo/rehberler/covid-19-rehberi/COVID-19_REHBERI_ ANTISITOKIN-ANTI_INFLAMATUAR_TEDAVILER_ KOAGULOPATI_YONETIMI.pdf).

36. Chen X, Zhao B, Qu Y, et al. Detectable serum SARSCoV-2 viral load (RNAaemia) is closely associated with drastically elevated interleukin 6 (IL-6) level in critically ill COVID-19 patients. Clin Infect Dis. 2020; ciaa449.

37. Shen, C, Wang, Z, Zhao F, et al. Treatment of 5 critically Ill patients with COVID-19 with convalescent plasma. JAMA. 2020;323(16):1582-1589.

38. Casadevall A, Pirofski L, The convalescent sera option for containing COVID-19. J Clin Invest. 2020;130:1545-1548.

39. T.C. Sağlık Bakanlığı Sağlık Hizmtleri Genel Müdürlüğü, Kan ve Kan Ürünleri Dairesi Başkanlığı. Covid-19-immunkonvalesan-plazma-tedarik-ve-klinik-kullanim-rehberi (https://dosyamerkez.saglik.gov.tr/Eklenti/37341,covid-19immun-konvalesan-plazma-tedarik-ve-klinik-kullanimrehberi-guncel--r1-v1pdf.pdf?0).

40. Zhu Z, Lu Z, Xu T, Chen C, Yang G, Zha T, Lu J, Xue Y. Arbidol monotherapy is superior to lopinavir/ritonavir in treating COVID-19. J Infect. 2020;81(1):e21-e23.

41. Fowler AA, Truwit JD, Hite RD, Morris PE, et al. Effect of vitamin $\mathrm{C}$ infusion on organ failure and biomarkers of inflammation and vascular injury in patients with sepsis and severe acute respiratory failure: The CITRIS-ALI randomized clinical trial. JAMA. 2019;322:1261-1270.

42. Ali N. Role of vitamin D in preventing of COVID-19 infection, progression and severity. J Infect Public Health. 2020;S18760341(20)30531-1.

43. Blaser AR, Starkopf J, Alhazzani W, et al. Early enteral nutrition in critically Ill patients: ESICM clinical practice guidelines. Intensive Care Med. 2017;43:380-398.

44. Cheng Y, Luo R, Wang K, et al. Kidney disease is associated with in-hospital death of patients with COVID-19. Kidney Int. 2020 May;97(5):829-838.

45. Adapa S, Aeddula NR, Konala VM , et al. COVID-19 and renal failure: Challenges in the delivery of renal replacement therapy. J Clin Med Res. 2020;12(5):276-285. 
46. Huang L, Zhang W, Yang Y, et al. Application of extracorporeal membrane oxygenation in patients with severe acute respiratory distress syndrome induced by avian influenza a (H7N9) viral pneumonia: National data from the chinese multicentre collaboration. BMC Infect Dis. 2018;18:23.

47. Abrams D, Ferguson ND, Brochard L, et al. ECMO for ARDS: From salvage to standard of care? Lancet Respir Med. 2019;7(2):108-110.

48. Huang C, Wang Y, Li X, et al. Clinical features of patients infected with 2019 novel coronavirus in Wuhan, China. Lancet. 2020;395(10223):497-506.

49. Klok FA, Kruip MJHA, Meer NJM, et al. Incidence of thrombotic complications in critically Ill ICU patients with COVID-19. Thromb Res. 2020;191:145-147.
50. European resuscitation council COVID-19 guidelines-24.April.2020 (https://erc.edu/sites/5714e77d5e615861f00f7d18/content_entry5ea884fa4c84867335e4d1ff/5ea885f34c84867335e4d20e/files/ERC_covid19_pages.pdf?1588257310).

51. Centers for disease control and prevention. Interim infection prevention and control recommendations for healthcare personnel during the coronavirus disease 2019 (COVID-19) pandemic June 19, 2020. (https://www. cdc.gov/coronavirus/2019-ncov/hcp/infection-controlrecommendations.html).

52. The Australian and New Zealand Intensive Care Society (ANZICS) COVID-19 Guidelines. Intensive care management of coronavirus disease 2019 (COVID-19): Challenges and recommendations. (https://www.anzics.com.au/wp-content/ uploads/2020/04/ANZI_3367_Guidelines_V2.pdf) 